\title{
Globalization of pediatric research: pharmacological RCTs in Latin America
}

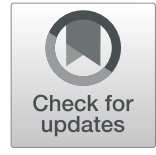

Federica Arienti ${ }^{1,2}$, Claudia Pansieri ${ }^{1 *}$ (D), Chiara Pandolfini ${ }^{1}$, Andrea Biondi ${ }^{2}$ and Maurizio Bonati ${ }^{1}$

\begin{abstract}
Globalization caused a shift in trial locations towards low-middle income countries, raising ethical concerns. These include the risk that conditions primarily affecting children in these countries will be neglected in favor of those affecting developed countries. We analyzed 253 published and 69 ongoing pharmacological RCTs performed in Latin America between 2000 and 2015 involving exclusively children. While over 50\% of the previously highly investigated diseases were no longer priorities, other diseases acquired greater attention in recent years. Brazil and Mexico resulted as the most active countries. A large gap remains between the real needs of children in these countries and scientific research.
\end{abstract}

Keywords: Globalization, Developing countries, Latin America, Randomized clinical trials

The number of randomized controlled trials (RCTs) in children, limited in the past due to ethical, physiological, pharmacometric challenges [1] and to low profitability, [2] has grown following several legislative initiatives, albeit with continuing challenges [3] and considerable heterogeneity across geographical regions. [4] In this context, we performed a literature review in Medline to determine the number of pediatric clinical trials conducted in Latin America and the Caribbean (LAC) in the last 16 years $(01 / 01 / 2000-31 / 12 / 2015$ period) to understand if the therapeutic areas studied in these low-middle income countries (LMICs) were pertinent to local health care needs. We compared these results with ongoing studies, and therefore with the future direction of research, obtained via a scoping review of ClinicalTrials.gov. Only RCTs classified as "Drug" were retained and analyzed further. Furtermore, we chose the three most prevalent diseases, and compared them with the conditions causing the greatest pediatric burden of disease in LAC [5].

253 of 1254 (21\%) published and 69 ongoing pharmacological RCTs resulted pertinent and were analyzed. The majority of these (60\%) were conducted in Brazil and Mexico. Diseases of the respiratory system, followed by certain infectious and parasitic diseases were the target

\footnotetext{
* Correspondence: claudia.pansieri@marionegri.it

${ }^{1}$ Laboratory for Mother and Child Health, Department of Public Health, IRCCS - Istituto di RicercheFarmacologiche "Mario Negri", Via Giuseppe la Masa 19, 20156 Milan, Italy

Full list of author information is available at the end of the article
}

of the majority of both published (33\%) and ongoing (41\%) RCTs.Over $50 \%$ of the previously highly investigated diseases, such as the Symptoms, Signs and Abnormal Clinical and Laboratory Findings not elsewhere classified (SSACLF), and certain conditions originating in the perinatal period, were no longer priorities.

The three most prevalent diseases, asthma, pneumonia, and giardiasis, had 21, 9, and 8 published RCTs, respectively. Salbutamol was the most used drug in the asthma trials $(5 / 18 ; 28 \%)$, while, among the systemic antibiotics, amoxicillin was the most studied in bacterial pneumonia treatment $(3 / 5 ; 60 \%)$. Mebendazole was the most used drug for giardiasis $(3 / 7 ; 43 \%)$. Of the ongoing studies, 9 concerned asthma, 5 pneumonia, and none addressed giardiasis. The majority of the drugs being studied for asthma were inhaled corticosteroids such as fluticasone and beclomethasone. Against viral pneumonia, 4 RCTs concerned new generation monoclonal antibodies and one trial studied an old antiviral drug, oseltamivir. None of the ongoing trials address bacterial pneumonia or giardiasis.

In the last 16 years, the most studied drugs in the treatment of asthma were Short Acting $\beta$-Adrenergic and Long Acting $\beta$-Adrenergic (LABA), the two classes of $\beta$-Adrenergic drugs recommended by the The Global Initiative for Asthma 2015 guidelines. In the ongoing trials, different dosages of LABA and inhaled corticosteroids were being analyzed in safety and efficacy studies.

(C) The Author(s). 2019 Open Access This article is distributed under the terms of the Creative Commons Attribution 4.0 International License (http://creativecommons.org/licenses/by/4.0/), which permits unrestricted use, distribution, and reproduction in any medium, provided you give appropriate credit to the original author(s) and the source, provide a link to the Creative Commons license, and indicate if changes were made. The Creative Commons Public Domain Dedication waiver (http://creativecommons.org/publicdomain/zero/1.0/) applies to the data made available in this article, unless otherwise stated. 
Table 1 Comparison with the guidelines of the drugs studied in the published articles and the ongoing RCTs for the three prevalent diseases

\begin{tabular}{|c|c|c|c|c|}
\hline $\begin{array}{l}\text { Condition } \\
\text { Investigated }\end{array}$ & $\begin{array}{l}\text { Published } \\
\text { (2000-2015) }\end{array}$ & Guidelines & Treatment & Ongoing (2015) \\
\hline \multirow[t]{8}{*}{ Asthma } & $\begin{array}{l}\text { Salbutamol } \\
\text { (SABA) }\end{array}$ & \multirow[t]{8}{*}{$\begin{array}{l}\text { GINA (The Global Initiative for Asthma) } \\
2015\end{array}$} & Step 1: SABA & $\begin{array}{l}\text { Fluticasone/Salmeterol } \\
\text { (ICS + LABA) }\end{array}$ \\
\hline & $\begin{array}{l}\text { Formoterol } \\
(\text { LABA) }\end{array}$ & & Step 2: low dose ICS + SABA & $\begin{array}{l}\text { Beclometasone } \\
\text { dipropionate (ICS) }\end{array}$ \\
\hline & $\begin{array}{l}\text { Salmeterol } \\
\text { (LABA) }\end{array}$ & & Step 3: low dose ICS/LABA + SABA & $\begin{array}{l}\text { Budesonide/Formoterol } \\
\text { (ICS + LABA) }\end{array}$ \\
\hline & $\begin{array}{l}\text { Montelukast } \\
\text { (LTRA) }\end{array}$ & & Step 4: medium dose ICS/LABA + SABA & $\begin{array}{l}\text { Dexamethasone/ } \\
\text { Epinephrine (ICS) }\end{array}$ \\
\hline & Fluticasone (ICS) & & $\begin{array}{l}\text { Step 5: add-on treatment (omalizumab } \\
\text { or tiotropium) }\end{array}$ & Salbutamol (SABA) \\
\hline & Budesonide (ICS) & & & Magnesium Sulphate \\
\hline & Aminophylline & & & Lebrikizumab \\
\hline & Triamcinolone & & & \\
\hline \multirow[t]{8}{*}{ CAP } & Amoxicillin & \multirow{8}{*}{$\begin{array}{l}\text { IDSA (The Infectious Diseases Society of } \\
\text { America) } 2013\end{array}$} & Outpatients & \\
\hline & Azithromycin & & Amoxicillin & \\
\hline & Chloramphenicol & & Macrolide antibiotic & \\
\hline & & & Inpatients & \\
\hline & & & First line: Ampicillin or Penicillin G & \\
\hline & & & Second line: Ceftriaxone or Cefotaxime & \\
\hline & & & Macrolide $+\beta$-lactam antibiotic & \\
\hline & & & $\begin{array}{l}\text { Vancomycin or Clindamycin + } \beta \text {-lactam } \\
\text { antibiotic }\end{array}$ & \\
\hline \multirow{6}{*}{$\begin{array}{l}\text { Viral } \\
\text { Pneumonia }\end{array}$} & Palivizumab & & Influenza & Oseltamivir \\
\hline & Motavizumab & & Amantadine or Rimantadine & MEDI8897 \\
\hline & & & Oseltamivir or Zanamivir & ALS-008176 \\
\hline & & & RSV & REGN2222 \\
\hline & & & Palivizumab & JNJ-53718678 \\
\hline & & & Ribavirin & \\
\hline \multirow[t]{5}{*}{ Giardiasis } & Mebendazole & \multirow{5}{*}{$\begin{array}{l}\text { WGO (The World Gastroenterology } \\
\text { Organization) } 2012\end{array}$} & First line: Metronidazole & \\
\hline & Albendazole & & Second line: Tinidazole or Ornidazole & \\
\hline & Nitazoxanide & & & \\
\hline & Chloroquine & & & \\
\hline & Tinidazole & & & \\
\hline
\end{tabular}

Magnesium sulphate was also being studied in one Mexican, national level, ongoing efficacy trial. Only 3/9 ongoing trials on asthma were placebo-controlled.

Regarding pneumonia, the published studies mostly concerned the treatment of Community-Acquired Pneumonia with amoxicillin against $S$. pneumoniae or azithromycin against $M$. Pneumoniae, the two first line therapies recommended by the Infectious Diseases Society of America 2013 guidelines, while the ongoing research is focusing exclusively on the treatment of pneumonia caused by Respiratory Syncytial Virus with new generation monoclonal antibodies. All these RCTs were placebo-controlled, while the only pharmacokinetic trial concerned oseltamivir, the antiviral drug already used as a first line therapy for influenza. Finally, giardiasis has been treated with the most common anti-parasitic drugs in the last 16 years, as recommended by the World Gastroenterology Organization 2012 guidelines, and no clinical trial is currently underway on this disease. See Table 1 for details.

The number of published pediatric trials conducted in LAC has increased over the last 16 years, although this area's low investment in research remains a concern, [6] and may be due to the increased complexity of conducting trials in children in LMICs [7]. 
Many trials designed to improve therapies aimed at the US population enroll patients in a variety of countries. Up to one third of published pediatric clinical trials involve patients in LMICs [8]. This globalization of pediatric research has significant scientific advantages, including evaluating safety and efficacy in more heterogeneous populations and increasing the opportunity to impact on child health on a global scale, [8] but it also raises scientific and ethical concerns, including whether the research is relevant to the needs of the local populations, the scientific validity of extrapolating results from different patient populations, and the availability of health-related resources and therapies once trials end [9]. As in our findings, the therapeutic areas covered by published pediatric trials conducted in LAC seem appropriate given the burden of disease of the related diseases in the region. Despite the focus on respiratory, anti-infective and antiparasitic drugs, several other important research areaslack in public health intervention, such as injuries, congenital diseases, and perinatal conditions. Our findings are in line with recent evidence showing that in LMICs there has been a shift towards noncommunicable diseases (NCDs) [8] that are rightly being given increased attention. The rise of transitional, economy driven research, will place greater attention on NCDs, such as type 2 diabetes, increasing the risk that conditions primarily affecting children in the poorest regions of the world will be neglected [10].

The increasing attention on asthma treatment is justified by the high prevalence of this disease. The published research, such as the montelukast studies, seems to reflect the needs of children in high income countries, since this kind of drug is not easily accessible in LAC due to issues on price and distribution. Furthermore, the ongoing research on drugs such as beclometasone dipropionate and fluticasone/salmeterol, which are already contemplated in the practice guidelines, adds little new knowledge to the treatment of this growing disease. On the other hand, magnesium sulphate, addressed by an ongoing Mexican efficacy trial, really reflects current LAC pediatric research needs.

Regarding pneumonia, attention shifted from treatment, which is still reflected in the guidelines, to preventive strategies with new generation drugs,such as monoclonal antibodies,once again, not in favor of the pediatric patients of these countries.

Giardia is still a major cause of mortality and morbidity in this region but despite this, no new therapeutic strategy is currently being studied, and research focuses on preventive therapies that, however, are of poor economic interest for the rest of the world.

\section{Conclusions}

Much remains to be done to respond to the real needs of the pediatric population in these countries, as seen with the lack of ongoing trials on a disease with a large impact on mortality, such as Giardia. Scientific research addressing the many different pediatric infectious diseases should be made a worldwide priority and should involve collaborative efforts between countries, investigators, policy makers, and industry.

\section{Abbreviations}

ICS: Inhaled corticosteroids; IDSA: The Infectious Diseases Society of America; LABA: Long Acting $\beta$-Adrenergic; LAC: Latin America and the Caribbean; LMICs: low-middle income countries; NCDs: noncommunicable diseases; RCT: randomized controlled trials; SABA: Short Acting $\beta$-Adrenergic; SSACLF: Symptoms, Signs and Abnormal Clinical and Laboratory Findings not elsewhere classified

\section{Acknowledgements \\ Not applicable. \\ Funding \\ None. \\ Availability of data and materials \\ The datasets used and/or analysed during the current study are available from the corresponding author on reasonable request. \\ Authors' contributions \\ FA drafted the initial manuscript and carried out the initial analyses. CP and ChiaraP conceptualized data collection instruments, and coordinated and supervised data collection. $A B$ critically reviewed the manuscript. $M B$ conceptualized and designed the study, and critically reviewed the manuscript. All authors have approved the final manuscript as submitted and agree to be accountable for all aspects of the work.}

Ethics approval and consent to participate

Not applicable.

\section{Consent for publication}

Not applicable.

\section{Competing interests}

"The authors declare that they have no competing interests".

\section{Publisher's Note}

Springer Nature remains neutral with regard to jurisdictional claims in published maps and institutional affiliations.

\section{Author details}

${ }^{1}$ Laboratory for Mother and Child Health, Department of Public Health, IRCCS - Istituto di RicercheFarmacologiche "Mario Negri", Via Giuseppe la Masa 19, 20156 Milan, Italy. ${ }^{2}$ Department of Pediatrics, Hospital S. Gerardo/Fondazione MBBM, University of Milano-Bicocca, Monza, Italy.

Received: 8 June 2018 Accepted: 25 February 2019

Published online: 04 March 2019

\section{References}

1. Kern SE. Challenges in conducting clinical trials in children: approaches for improving performance. Expert Rev Clin Pharmacol. 2009;2:609-17.

2. Bourgeois FT, Murthy S, Pinto C, Olson KL, loannidis JP, Mandl KD. Pediatric versus adult drug trials for conditions with high pediatric disease burden. Pediatrics. 2012;130:285-92.

3. Ward RM, Benjamin DK Jr, Davis JM, Gorman RL, Kauffman R, Kearns GL, et al. The need for pediatric drug. Development. 2018;192:13-21. 
4. Glickman SW, McHutchison JG, Peterson ED, Cairns CB, Harrington RA, Califf $\mathrm{RM}$, et al. Ethical and scientific implications of the globalization of clinical research. N Engl J Med. 2009;360(8):816-23.

5. Global Burden of Disease Study 2013 Collaborators. Global, regional, and national incidence, prevalence, and years lived with disability for 301 acute and chronic diseases and injuries in 188 countries, 1990-2013: a systematic analysis for the Global Burden of Disease Study 2013. Lancet. 2015;386:743-800.

6. Benedetti V, Echeverria G, Riquelme I. Biomedical research in Latin America: we can do more. Lancet. 2016;387:941.

7. Joseph PD, Caldwell PH, Tong A, Hanson CS, Craig JC. Stakeholder views of clinical trials in low- and middle-income countries: a systematic review. Pediatrics. 2016;137(2):e20152800

8. Dunne J, Murphy MD, Rodriguez WJ. The globalization of pediatric clinical trials. Pediatrics. 2012;130:e1583-91.

9. Homedes N, Ugalde A. Availability and affordability of new medicines in Latin American countries where pivotal clinical trials were conducted. Bull World Health Organ. 2015;93:674-83.

10. Duke T, Fuller D. Randomised controlled trials in child health in developing countries: trends and lessons over 11 years. Arch Dis Child. 2014;99:615-20.

Ready to submit your research? Choose BMC and benefit from:

- fast, convenient online submission

- thorough peer review by experienced researchers in your field

- rapid publication on acceptance

- support for research data, including large and complex data types

- gold Open Access which fosters wider collaboration and increased citations

- maximum visibility for your research: over $100 \mathrm{M}$ website views per year

At BMC, research is always in progress.

Learn more biomedcentral.com/submissions 